\title{
persistência do não lugaar literário: ALGUMAS QUESTÕES COM JULIANO GARCIA PESSANHA
}

\section{Thiago H. Fernandes ${ }^{1}$}

Não rememoro quando se deu meu contato com a literatura de Juliano Garcia Pessanha; sei que, em termos cronológicos, se deu com atraso, descompasso que poderia desdobrar-se numa ansiedade leitora. Ao resenhar ${ }^{2}$ Recusa do não lugar, título que o autor publica em 2018, pensava ser válido afirmar a necessidade de trabalharmos (leitores críticos da obra) junto aos termos mais ou menos contratuais que o mesmo nos oferece, um glossário mínimo de muita valia na travessia de um terreno que se pode árduo e movediço. Mas estes facilitadores da tarefa analítica e interpretativa me parecem circunstanciais e provisórios; se negativam quando das exigências de uma literatura que sai à caça, e que parece se mover, antes de tudo, no tempo e no espaço de se fazer. Em sua extensão e complexidade, é matéria também desejante (me dou aqui o direito de afirmar), escorregadia ao império absoluto da interpretação, avessa aos conceitos acabados se única medida, ou seja, à pretensão nossa de controle, do perigo de um olhar panorâmico e generalizante. Há um convite que se restabelece em cada título de Pessanha, convite a uma postura crítica mais apaziguada, e não apenas, mas aberta à dúvida, ao desconhecido. E isto sabidamente é informado pela persistência de um não-lugar literário³.

A entrevista aqui registrada se deu especialmente para compor o número vigente da Opiniães. Na ocasião do envio das questões - por e-mail - a Juliano, antecipei um pedido de desculpas justamente pelo formato das mesmas; aproximaram-se de notas de leitura, o que assumi como intenção tardia. Por isso, me reporto numa redação menos precisa, às vezes dissimulando hipóteses, o que poderia antes coagir o entrevistado. Pela generosidade do autor a compor este diálogo, meu agradecimento; já pelo teste leitor dos enunciados, meu obrigado a Vinicius Garcia Pires.

1 Professor assistente de literatura na Universidade estadual do Piauí (UESPI). Doutorando em Literatura brasileira pelo DLCV/USP. E-mail: thiagohfernandesp@gmail.com

2 "Uma casa perto da casa dos homens para JP". Em tese (UFMG), Belo Horizonte, v. 24. n. 2, 2018. 3 Sabidamente o uso da expressão aqui é outro daquele que informa o conteúdo de Recusa do não lugar. 
Pela iluminação/incentivo de propor ao autor uma entrevista, meu último agradecimento a Eliane Robert Moraes.

$* *$

Juliano,

não dá para ignorar que a não especificidade na sua literatura é um traço marcante. $E$ isto se constata, essencialmente, na recombinação entre registros que você opera, o que resulta num devir mútuo entre literatura e filosofia. Sobretudo, e similar a outros textos literários, é obra que gera uma força contrária a uma política de controle. O que parece tão mais latente quando estamos em posição de crítica.

Digo força para não dizer tendência, uma tendência ao inespecífico como é também muito apontado na arte contemporânea em suas muitas expressões.

Lendo textos que versam sobre a sua obra é quase um imperativo apontar para essa questão da hibridização de registros e de gêneros, o que me parece arriscar-se, a esta altura, a uma limitação descritiva.

Eu te perguntaria, devolvendo a você uma posição mediadora, por que não superamos isso? Por que precisamos falar desse traço inespecífico da sua literatura?

$* *$

JGP: Confesso que tomei para mim os termos nos quais o Benedito Nunes prefaciou o primeiro livro, Sabedoria do nunca (1999), e em seguida um comentário excelente do Franklin Leopoldo e Silva aprofundou a análise da obra nesses mesmos termos. Eu adotei a palavra deles como explicitadora do que tinha feito. Eram dois críticos e filósofos que respeito. A partir daí fui apresentado e resenhado assim. E essa nomeação funcionou também editorialmente. Bem, em parte, porque ela também me excluiu de concorrer a prêmios literários que exigem a inscrição em um gênero determinado. 
Recentemente, terminei de escrever um livro que quero publicar. É uma espécie de autoficção filosófica, na qual os momentos ensaísticos estão incluídos numa narrativa contínua. Neste caso, não haverá a quebra usual por diferenciação de gênero que sempre caracterizou meus livros. De todo modo, o que Benedito e Franklin viram no começo não havia sido algo programado por mim, não era um projeto formal, bem como este último livro ainda inédito saiu como romance ou novela sem uma determinação prévia.

$* *$

Andei relendo algumas páginas de Paul Zumthor, seu Performance, recepção, leitura (2014). Pensando nos muitos impulsos e fluxos que formam o corpo da sua literatura, seria latente uma atenção demorada neste ponto do processo, ponto no qual se encontra o leitor em posição ativa.

Você conseguiria teorizar, digamos, ou fabular um pouco o leitor no além do que você escreve? Como se perguntássemos que leitor é esse que segura o seu livro, não num sentido sociológico, mas ideia de leitor. Ou seria talvez, que gesto leitor é esse requerido ao se estar diante da sua literatura?

$* *$

JGP: Nunca imaginei o leitor e não escrevi para ele. Minha escrita nasceu do fracasso acadêmico em produzir textos limpos nos moldes dos papers americanos. Eu fazia um mestrado sobre Heidegger na Unicamp e estava interessado nas situações-limite e em filosofia existencial. Meu orientador dizia que meus textos não serviam para a academia. Diante desta situação, eu poderia forçar uma escrita sobre a experiência sem a experiência ou tomar os diários que fazia já há muitos anos e incluir-me na escrita. Fui pelo segundo caminho, afinal, eu mesmo me via como alguém atravessado pelas questões do extremo que estudava em Heidegger e seus herdeiros. Além disso, era mais "confortável" escrever usando os meus diários do que escrever nos moldes acadêmicos, visando um leitor que poderia me 
acusar de incompetência. Ao usar minhas experiências, eu fugia dessa acusação, pois não poderia ser desmentido. Essa foi a gênese dessa filosofia existencial heterotanatográfica (o ninguém, o vazio) e heterobiográfica (o outro) que caracteriza o meu trabalho. O leitor pesou na hora de fugir, depois ele desapareceu.

$* *$

Numa entrevista à revista Teresa, perguntado sobre a forma literária, você conclui sua fala com a constatação: "é uma palavra de travessia do instituído. Uma forma literária entre o e-mail e a oração (entre a captura da informação e o pressentimento do poema)". ${ }^{4}$

Este sentido de travessia, como algo que perfura, me parece ser uma constante força motriz da sua escrita. Isto me faz pensar se escrever para você seria essencialmente um gesto, gesto que se faz no momento presente, que é condicionado pela tensão do instante de se fazer gesto.

O que eu afirmo poderia ser antes uma pergunta a você direcionada; mas o ponto em que quero mesmo tocar é o seguinte: a sua obra se perguntou muito sobre como estar presente; a palavra "duração" retém um lugar especial nos seus escritos.

Você acredita que seria possível afirmar que esse questionamento também diz respeito à literatura? É possível dizer que a sua literatura é marcada pela interrogação sobre como estar presente, não sendo apenas isso matéria da "ficção" que você construiu ao longo desses anos?

$* *$

JGP: Já não acredito numa travessia absoluta, numa migração do instituído para o aberto. Perdi esta mania revolucionária do paradiso terrestre e desloquei-me da posição profética. Recusa do não-lugar foi a marca dessa mudança.

4 PESSANHA, J. G. Juliano Garcia Pessanha. Teresa (USP), São Paulo, n. 10-11, p. 48, 2010. 
Há travessias e perfurações, mas se vai de um lugar para outro e o lugar no qual se chega também já foi visitado. O próprio aberto, a dimensão alética, ou a indiferenciação mística são territórios já visitados e demarcados.

Ruminei muito sobre o estar presente e o estar ausente na cena do mundo. No registro psicológico, acredito que o gesto da minha escrita é indissociável do combate para chegar a si mesmo. Por isso há relatos heterotanatográficos, de quem começou como despencado, e heterobiográficos, de quem encontrou seres e coisas fertilizadoras e propiciadoras de incorporação. Daí o termo "testemunho transiente" - que batizou a reunião de minha tetralogia: nascemos e encontramos ou desencontramos a hospitalidade. Alguns ficam nutridos por fluxos de estabilidade, outros precisam lutar pela continuidade. De qualquer modo se pode relatar ou não. Talvez não seja necessário, mas alguns têm essa paixão de contar o que se passou ou o que não se passou. O testemunho é transiente porque há deslocamento. Eu, por exemplo, migrei de uma posição romântico-libertária de elogio da borda para uma tentativa de integração no mundo complexo. Nesse sentido, fui de uma heterotanatografia extemporânea para uma hetero biografia mundana.

$* *$

Talvez o que eu diga aqui seja um desdobramento do antes pensado. A despeito da guinada operada por você em Recusa do não-lugar, num movimento de revisão, e ainda me referindo especialmente a prática de escrita.... quando você escreve, se dedica a um novo texto, a um novo conjunto de textos que pode vir a ser um futuro livro, é uma volta ao princípio do gesto de escrever? Ou você de fato estaria hoje, no dia de hoje, cinco e mais outros livros adiante neste processo da escrita?

Afinal, parece conviver na sua obra dois sentidos de movimento: há fluxo, há um giro de matéria, ao mesmo tempo há retenção, como numa espécie de reiteração. 
JGP: Só posso subscrever a pergunta: há um giro de matéria (por exemplo, de Heidegger e Kafka para Sloterdijk e Winnicott) e ao mesmo tempo uma reiteração (o modo de dizer). Quando lancei Recusa do não-lugar, na Feria Plana, em 2018, aconteceu uma performance e em seguida o público formulou algumas perguntas. Diante de minha dificuldade em responder uma dessas questões, um amigo escritor, o Evandro Affonso Ferreira, que se encontrava na plateia disse: "Ele mudou de estrada, mas continua no acostamento". O gesto escritural continua plantado no mesmo lugar.

$* *$

E em sendo o caso da pertinência do gesto de escrever calcado no instante, até que ponto esse mesmo gesto não se mistura ou se mistura com um romance não romance sobre o escritor (e não digo do sujeito biográfico, clínico) Juliano Garcia Pessanha?

$* *$

JGP: Há um romance não romance sobre o escritor Juliano Garcia Pessanha, mas esse nome guarda também a impessoalidade poética. A assinatura remete a um lugar de onde se diz um sentimento do mundo. Preocupame menos a arquitetura de uma história, com suas técnicas de desenvolvimento, do que a explicitação filosófico-psicológica do "protagonista", entre aspas, pois, como já disse, ele transcende o sujeito empírico-autoral. O estilo perdura, mas se no primeiro momento a singularidade pensa ultrapassar o mundo e anunciar novas constelações (a tetralogia), no segundo, o mundo faz a singularidade ajoelhar-se para o efetivo (Recusa do não-lugar e o que está no prelo). Esse percurso filosófico de Kierkgaard e Chestov para Hegel e Sloterdijk, por exemplo, me interessa 
mais que o literário e o romanesco, embora seja certo que tudo pode caber em um romance.

Existe um trecho na seção primeira de Instabilidade Perpétua, publicado em 2009 e que recobrarei daqui em diante, em que você fala sobre a casa. "Seríamos demitidos de nossa casa e nossa casa é o buraco branco"s. A imagem da casa segue ressoando na sua poética.

Por mais que a literatura já seja por si um espaço solitário, você consegue se ver em relação à grande casa da literatura brasileira? Quero dizer, em relação a essa noção de uma grande narrativa literária?

$* *$

JGP: Se a explicitação psicológica-filosófica da situação do "protagonista" entre filosofias existenciais da singularidade e filosofias de diagnóstico epocal foi para mim o mais decisivo, então, autores como Musil e Gombrowicz e filósofos como Heidegger e Sloterdijk foram mais importantes que a tradição romanesca brasileira. Talvez por conta disso haja poucos aposentos perto do meu na casa da literatura brasileira. Entretanto, minha língua é a portuguesa, nunca morei fora do Brasil e todo o recolhido nesses livros poderia, sim, ser objeto de uma análise literária do tipo sociológica que, facilmente, poderia identificar questões de grupo social tipicamente brasileiras.

$* *$

5 PESSANHA, J. G. Instabilidade perpétua. In: Testemunho transiente. São Paulo: SESI SP Editora, 2018. n.p. (e-book). 
"Para cada "mundo" existe um antimundo e um contramundo. Para todo não mundo, uma passagem. Implosão e explosão contínuas, instabilidade perpétua." 6

Esse é o grande parágrafo final da seção a que me refiro de Instabilidade perpétua; trecho que me faz pensar em ressonâncias, outro termo verificável no mesmo texto e que, aliás, tem constado como um modo possível de ser da sua literatura.

A sua obra ressoa algo que já foi muito latente em alguns "lugares" da literatura brasileira contemporânea, em especial ao rascunho de um "antimundo", de um "contramundo". Uma literatura que também se perguntou muito pela presença, pelo estar no mundo e acabou encontrando no corpo uma morada, como tão forte é nos escritos dos anos 80 (margeados pelo antes).

Você parece recuar ainda mais. Nunca houve bem um corpo possível. Sua presença mais marcante em Recusa do não-lugar já não foge a uma debilidade, ao assessoramento médico. Parece não haver então uma espacialidade possível para um "antimundo", um "contramundo"... seria isto agora apenas matéria da poesia que ficou para trás?

$* *$

JGP: Como disse no início da terceira resposta, acredito em antimundos e contramundos, mas toda a multiplicidade deles estaria situada no interior do mundo enquanto sistema global consumado. O que não há mais é um antimundo para este "universal-planetário" em cujo interior existimos. Não há um outro começo além da técnico-ciência para ficar com a ruptura de Heidegger e nem um início além do monetário e da mercadoria para falar com Marx. A geleia geral do presentismo está estabelecida e, por sorte ou azar, a história resfriou. A questão que resta para nós é a de gerir os problemas climáticos e sanitários de modo que a civilização não termine neste século: o consumo terá de diminuir e os hábitos se transformarem. Dito

6 PESSANHA. J. G. Instabilidade perpétua. In: Testemunho transiente. São Paulo: SESI SP Editora, 2018. n.p. (e-book). 
isso, penso que a palavra poética em transição e carregada de afeto a torna diferente dos enunciados que circulam pelo mundo.

$* *$

Pensando ainda em ressonâncias.... o João Gilberto Noll tem o conto de nome Marilyn no inferno, que consta em $O$ cego e a dançarina de 1980. 0 protagonista é um figurante no primeiro western rodado no Brasil, de acordo com o narrador. Há uma imagem no mesmo que desejo destacar:

"[...] lá vai o rapazinho agarrado ao pescoço do cavalo, o cév e a terra são uma coisa só, Caxias está perto, muito perto, quase chegando, o rapazinho já vê os primeiros prédios e chaminés, lá vai o rapazinho com medo de que o cév e a terra se rasguem no ponto em que se encontram mas nenhum medo de que nada se rasgue porque é boa a vertigem [...]." ${ }^{\prime \prime}$

Por algum motivo, este ponto em que céu e terra se encontram, ameaça de seu rompimento, sempre me remeteu a sua literatura. O que se ameaça no conto de Noll como queda naquele espaço do após, me parece ser um lugar possível de se anotar em seus textos, lugar a partir do qual se moveria um "alguém" virtual, não biográfico que ali opera.

Isto me parece inclusive muito próximo do mote básico da seção primeira de Instabilidade perpétua, justamente a respeito de uma topologia nomeada: "[...]: há uma linha de horizonte, há um desfiladeiro frágil entre o buraco negro, onde zanzam os abismais, e o buraco branco, onde erram os figurantes." 8

Penso numa proximidade entre topologias, do espaço da subjetividade e do espaço do espetáculo, ambos expostos a partir de um esvaziamento, não mais o grande teatro do mundo, mas o mundo exposto em sua artificiosidade.

7 NOLL, João Gilberto Noll. O cego e a dançarina. Rio de Janeiro: Record, 2008. p. 40.

8 PESSANHA, J. G. Instabilidade perpétua. In: Testemunho transiente. São Paulo: SESI SP Editora, 2018. n.p. (e-book). 
Talvez eu deseje a sua mediação: quão impertinente ou possível seria uma aproximação como esta?

JGP: A literatura para mim é rasgo e transição: o lugar onde emerge a atmosfera e a imagem. É aí que o afeto eclode e o pescoço da palavra é retorcido. Se a literatura da competência narratológica é superada pelo historiador e pelo especialista que escreve bem e a literatura do pragmatismo americano termina no panfletismo do politicamente correto, resta o ponto do rasgo entre céu e terra. Neste espaço reduzido de transição entre o dentro e fora, a argamassa do afeto protege a palavra de virar mero signo e mero enunciado. A transicionalidade protege também a palavra do eu empírico e da voz autoral. Por isso, como está formulado na pergunta, há sempre um alguém virtual não biográfico. A transiência foradentro permite dizer a atmosfera do mundo e a experiência dele para além da subjetividade.

$* *$

Encontrei há pouco uma dissertação de mestrado sobre a sua obra assinada por Francine Rodrigues e defendida na PUC de São Paulo. O título já é esclarecedor, A escrita rítmica de Juliano Garcia Pessanha. Me parece ser aquele tipo de estudo que nos surpreende por, de alguma maneira, desprogramar o modo como se tem mirado a obra de um certo autor.

Penso em primeiro.... qual seria o nível de controle [voltando a um termo do começo] aplicado por você a seus textos numa etapa pós-escrita?

E expandindo esse mesmo ponto, em algum momento você já se pautou pela intenção que antecipa um efeito a que deve a obra dar conta? Ou será sempre uma ilusão da arte se propor a isto, a antecipar não apenas efeitos, mas quem sabe, também afetos? 
Além disso (longe de me referir a um trabalho direcionado ao dever do ritmo e da melodia, por exemplo), como se descortinaria para você a possibilidade do fazer literário se distender do racional, e jogar junto, digamos, da maleabilidade da palavra?

JGP: Creio que o passeio ansioso pela desconstituição do eu (transiência) garante a condensação da palavra e sua chegada súbita, vertical. Para um corpo exposto, com déficit de preenchimento, mesmo a palavra lida, quando transcrita, carrega uma atmosfera. Tem algo de grito ou de festa. A exaltação intensiva garante que o signo não caia no estado de enunciado. Para mim, não há uma pós-escrita. O escrever, ele mesmo, já é uma transcrição das palavras que ficaram encubadas muito tempo num corpo vazio. No que diz respeito ao tema da burilação e do enxugamento estético posterior, posso dizer que não pratico: já escrevo cada frase como se fosse o último recado que alguém pode enviar sem direito a rascunho. 